\title{
Effect of Fertilizers on the Incidence of Anthracnose Disease, Yield and Quality of Mango
}

\author{
M.N.A CHOWDHURY ${ }^{*}$ AND M.A. RAHIM ${ }^{2}$ \\ ${ }^{1}$ Spices Research Center, Bangladesh Agricultural Research Institute, Shibganj, Bogra, Bangladesh \\ ${ }^{2}$ Department of Horticulture, Bangladesh Agricultural University, Mymensingh, Bangladesh
}

\begin{abstract}
Effect of different fertilizers on the control of anthracnose disease, yield and quality of mango cv Amrapali was investigated. Application of combined fertilizers gave the highest fruit set, fruit retention and fresh fruits, therefore, produced the highest yield per plant and per hectare. The highest number of healthy fruits was found from $2^{\text {nd }}$ year crop and the lowest was obtained from $1^{\text {st }}$ year. The highest (8.47 t/ha) yield was obtained from $2^{\text {nd }}$ year and the lowest $(4.58 \mathrm{t} / \mathrm{ha})$ was obtained from $1^{\text {st }}$ year

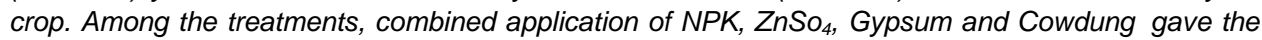
highest (50.67) number of healthy fruits and the lowest (16) was obtained from untreated plant. The

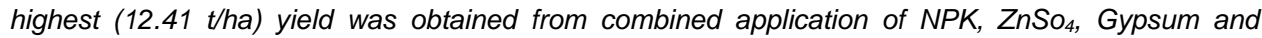
Cowdung and the lowest (3.88 t/ha) was obtained from untreated plant. In respect of combined effect, the highest (15.22 t/ha) yield was obtained from $2^{\text {nd }}$ year $\times T_{9}$ treated plant and the lowest (2.95 t/ha) was found in untreated $1^{\text {st }}$ year plant.
\end{abstract}

Key words: Mango, fertilizers, anthracnose, yield.

\section{INTRODUCTION}

Mango (Mangifera indica L) belongs to the family Anacardiaceae, originated in South Asia or Malayan archipelago. In Bangladesh in terms of total area and production of fruit crops, mango ranks first in area and third in production. It occupies 50990 hectares of land and total production is 242605 tons per annum with an average yield of 4.75 tons per hectare (BBS, 2005). But the yield is very low compared to that of India, Pakistan and many other mango growing countries in the world (Hossain and Ahmed, 1994). In Bangladesh most of the farmers do not follow the modern practices of mango cultivation including manuring. Chemical control of mango anthracnose is very expensive for a poor farmer and it also creates environmental pollution. Fertilizers have given effective result against anthracnose disease. Very little work has so far been done in Bangladesh and abroad on the use of manures and fertilizers for controlling the anthracnose disease of mango through use of fertilizers. Therefore, the present study was taken to determine the effects of fertilizers in controlling mango anthracnose.

\footnotetext{
* Corresponding author: Senior Scientific Officer, Spices Research Center, BARI, Shibganj, Bogra

(C) 2006 School of Agriculture and Rural Development, Bangladesh Open University, All rights reserved.
} 


\section{MATERIALS AND METHODS}

The investigation was carried out from July 2000-2001 and July 2001-2002 at Germplasm Centre (GPC), FTIP, Department of Horticulture, BAU, Mymensingh. The single-factor experiment was conducted in randomized complete block design (RCBD) with 3 replications. The treatments were Cowdung ( $\left.T_{1}\right)$; Mustard oil cake $\left(T_{2}\right)$; Urea $\left(T_{3}\right)$; TSP $\left(T_{4}\right)$; MP $\left(T_{5}\right)$; Gypsum $\left(T_{6}\right)$; Zinc sulphate $\left(T_{7}\right) ; C D+M O C\left(T_{8}\right) ; N P K+$ Zinc sulphate + Gypsum $\left(T_{9}\right) ; P K+$ Zinc sulphate $\left(T_{10}\right) ; \mathrm{K}+$ Zinc sulphate $\left(T_{11}\right)$ and Control $\left(T_{12}\right)$. The organic manures, well decomposed cowdung and mustard oil cake and the inorganic fertilizers- urea, TSP, MP, zinc sulphate and gypsum were used in the experiment. The organic manures and inorganic fertilizers were applied separately and also combindely during the month of July-August. The combinations of organic manures were cowdung + Mustard oil cake. Before fertilization, weeding was done and basin type furrows around the trees $100 \mathrm{~cm}$ away from the base of the tree were prepared with spade. Manures and fertilizers were applied in the furrows and then thoroughly mixed with the soil. Mustard oil cakes were decomposed in water for three days before these were mixed with the furrow soils. Fertilizers were applied in the following rates.

\begin{tabular}{ll}
\hline MANURES AND FERTILIZERS USED & Quantity/tree \\
\hline \hline Cowdung & $20 \mathrm{~kg}$ \\
Mustard oil cake (MOC) & $2 \mathrm{~kg}$ \\
Urea & $250 \mathrm{~g}$ \\
TSP & $250 \mathrm{~g}$ \\
MP & $350 \mathrm{~g}$ \\
Gypsum & $100 \mathrm{~g}$ \\
Zinc sulphate & $10 \mathrm{~g}$ \\
CD+MOC & $10 \mathrm{~kg}+2 \mathrm{~kg}$ \\
CD+NPK+Gypsum+Zinc sulphate & $10 \mathrm{~kg}+250 \mathrm{~g}+250+350 \mathrm{~g}+100 \mathrm{~g}+10 \mathrm{~g}$ \\
PK+Zinc sulphate & $250 \mathrm{~g}+350 \mathrm{~g}+10 \mathrm{~g}$ \\
K+Zinc sulphate & $350 \mathrm{~g}+10 \mathrm{~g}$ \\
Control (Untreated) & 0.00 \\
\hline
\end{tabular}

The variety was Amrapali and spacing was $2.5 \mathrm{~m} \times 2.5 \mathrm{~m}$. Pooled analysis was also done in this experiment. The recorded parameters were fruit retention per inflorescence and per plant (\%); total number of healthy fruits per inflorescence and per plant (\%); total number of diseased fruits per inflorescence and per plant (\%); \% fruit area diseased/ Severity; fruit weight (g); Yield/plant; yield (t/ha) and total soluble solids (TSS). The benefit-cost ratio (BCR) analysis was calculated. Horsfall and Barratt (1945) grading scale was used for calculating disease severity. TSS was determined by reflactometer.

\section{RESULTS AND DISCUSSION}

\section{Yield and yield contributing characters}

Different years resulted insignificant variation in fruit set per inflorescence (Table 1). The highest fruit retention per inflorescence and per plant (1.72 and $11.31 \%$ respectively) was observed in 2 nd year and the lowest (1.41 and $10.25 \%$ respectively) was found in 1st year at 60 DAFS (Table 1). In $2^{\text {nd }}$ year the plants gave the highest fruit set, fruit retention per inflorescence and per plant. This might be due to the age of the plant and environmental factor, which led to the highest fruit set and retention per inflorescence and per plant. Significant difference on total number of fruits per plant was found due to different years (Table 1 ). The highest (44.83) number of fruits per plant was found in $2^{\text {nd }}$ year and the lowest $(20.19)$ number was recorded from $1^{\text {st }}$ year. Insignificant effect was found on weight of individual fruit due to different years. Significantly the highest $(5.30 \mathrm{~kg})$ fresh fruit yield per plant was found in $2^{\text {nd }}$ year and the lowest $(2.83 \mathrm{~kg})$ yield was obtained from $1^{\text {st }}$ year. In $2^{\text {nd }}$ year gave the highest $\left(8.47 \mathrm{t} / \mathrm{ha}\right.$ ) yield and the lowest $(4.58 \mathrm{t} / \mathrm{ha})$ was obtained from $1^{\text {st }}$ year. In $2^{\text {nd }}$ year the number of fruits per plant, number of healthy fruits per plant, and yield per plant and per hectare increased compared to $1^{\text {st }}$ year. The results indicated that 2 nd year gave higher fruit set and fruit retention, which led to the more fruit per plant and per hectare. 
Table 1. Effect of manures and fertilizers on fruit set, fruit retention and yield of mango cv Amrapali

\begin{tabular}{|c|c|c|c|c|c|c|c|c|c|c|c|}
\hline \multirow[t]{2}{*}{ Treatments } & \multirow[t]{2}{*}{ FS/I } & \multicolumn{3}{|c|}{$\begin{array}{c}\text { Fruit retention/ } \\
\text { inflorescence } \\
\text { at different DAFS }\end{array}$} & \multicolumn{3}{|c|}{$\begin{array}{c}\text { Fruit retention/plant } \\
\text { (\%) at different } \\
\text { DAFS }\end{array}$} & \multirow[t]{2}{*}{$\begin{array}{l}\text { TNFI } \\
\text { plant }\end{array}$} & \multirow[t]{2}{*}{$\begin{array}{l}\text { Wt. of } \\
\text { indi. } \\
\text { fruit (g) }\end{array}$} & \multirow[t]{2}{*}{$\begin{array}{c}\text { H F } \\
\text { Yield } \\
t(\mathrm{Kg})\end{array}$} & \multirow[t]{2}{*}{$\begin{array}{l}\text { H F } \\
\text { Yield } \\
\text { (t/ha) }\end{array}$} \\
\hline & & 20 & 40 & 60 & 20 & 40 & 60 & & & & \\
\hline $1^{\text {st }}$ year & 13.97 & 6.04 & 2.21 & 1.41 & 44.36 & 15.89 & 10.25 & 20.19 & 198.50 & 2.83 & 4.58 \\
\hline $2^{\text {nd }}$ year & 15.22 & 6.45 & 2.52 & 1.72 & 42.58 & 16.69 & 11.31 & 44.83 & 186.92 & 5.30 & 8.47 \\
\hline LSD 5\% & 2.16 & 0.72 & 0.11 & 0.13 & 0.63 & 1.56 & 1.07 & 6.85 & 12.64 & 0.98 & 1.21 \\
\hline $1 \%$ & 3.59 & 1.19 & 0.18 & 0.21 & 1.05 & 2.59 & 1.78 & 4.13 & 20.95 & 1.62 & 2.01 \\
\hline $\begin{array}{c}\text { Level of } \\
\text { Significance }\end{array}$ & NS & NS & ** & ** & ** & NS & * & ** & NS & ** & $\star \star$ \\
\hline $\mathrm{T}_{1}$ & 13.77 & 5.33 & 2.10 & 1.53 & 39.00 & 15.50 & 11.33 & 34.50 & 192.50 & 4.29 & 6.86 \\
\hline $\mathrm{T}_{2}$ & 15.47 & 5.93 & 2.63 & 1.47 & 39.17 & 17.33 & 9.83 & 32.50 & 188.50 & 3.80 & 6.08 \\
\hline $\mathrm{T}_{3}$ & 15.03 & 6.37 & 2.00 & 1.27 & 44.00 & 13.83 & 8.83 & 27.50 & 191.50 & 3.17 & 5.07 \\
\hline $\mathrm{T}_{4}$ & 13.40 & 6.20 & 1.97 & 1.10 & 46.33 & 14.83 & 8.33 & 23.83 & 196.00 & 2.89 & 4.62 \\
\hline $\mathrm{T}_{5}$ & 15.37 & 6.08 & 2.60 & 1.63 & 40.00 & 17.17 & 10.67 & 28.00 & 192.00 & 3.27 & 5.23 \\
\hline $\mathrm{T}_{6}$ & 12.37 & 5.63 & 2.10 & 1.30 & 45.83 & 16.50 & 10.83 & 23.00 & 193.00 & 2.72 & 4.35 \\
\hline $\mathrm{T}_{7}$ & 14.47 & 5.57 & 2.27 & 1.50 & 39.33 & 15.83 & 11.00 & 29.50 & 195.00 & 3.74 & 5.98 \\
\hline $\mathrm{T}_{8}$ & 14.70 & 6.90 & 2.67 & 1.87 & 48.33 & 19.00 & 13.17 & 45.50 & 189.00 & 6.08 & 9.73 \\
\hline $\mathrm{T}_{9}$ & 17.60 & 8.27 & 3.53 & 2.35 & 49.00 & 20.17 & 12.83 & 56.67 & 185.00 & 7.76 & 12.41 \\
\hline $\mathrm{T}_{10}$ & 16.23 & 7.72 & 2.77 & 2.08 & 48.33 & 17.33 & 12.83 & 38.50 & 191.00 & 4.98 & 7.97 \\
\hline $\mathrm{T}_{11}$ & 14.77 & 6.13 & 2.17 & 1.70 & 41.83 & 14.67 & 11.67 & 31.00 & 195.00 & 3.71 & 5.94 \\
\hline $\mathrm{T}_{12}$ & 11.97 & 4.83 & 1.57 & 0.97 & 40.50 & 13.33 & 8.00 & 19.67 & 203.50 & 2.42 & 3.88 \\
\hline LSD 5\% & 1.26 & 1.04 & 0.45 & 0.19 & 2.51 & 1.43 & 0.93 & 1.09 & 7.73 & 0.44 & 1.33 \\
\hline $1 \%$ & 2.08 & 1.39 & 0.33 & 0.20 & 3.36 & 1.91 & 1.24 & 1.45 & 10.32 & 0.58 & 2.89 \\
\hline $\begin{array}{c}\text { Level of } \\
\text { Significance }\end{array}$ & ** & ** & ** & $\star *$ & $\star *$ & $\star \star *$ & ** & $\star \star *$ & ** & ** & ** \\
\hline \multicolumn{5}{|c|}{$\begin{array}{l}\text { FS/I = Fruit set } / \text { Inflorescence at the initial stage } \\
\text { DAFS = Days after fruit set } \\
\text { TNF = Total number of fruits } \\
\text { HF = Healthy fruit } \\
\text { DF = Diseased fruit } \\
* \star=\text { Significant at } 1 \% \text { level } \\
*=\text { Significant at } 5 \% \text { level } \\
\text { NS = Not significant } \\
\text { Spacing }=2.5 \mathrm{~m} \times 2.5 \mathrm{~m} \\
\text { BCR }=\text { Gross return } / \text { Total cost of production } \\
\text { Note = Price of mango was considered to be TK } 20 / \mathrm{kg}\end{array}$} & \multicolumn{6}{|c|}{$\mathrm{T}_{1}=$ Cowdung $(\mathrm{CD})$} & \\
\hline
\end{tabular}

There was highly significant variation was observed in respect of fruit set per inflorescence as influenced by different treatments (Table 1 ). It was observed that treatment $T_{9}$ produced the highest (17.60) fruit set per inflorescence while control gave the lowest (11.97) in this regard. Fruit retention per inflorescence and per plant at different days after fruit set (DAFS) was significantly influenced by different fertilizers (Table 1). The highest (2.35) number of fruit retention was recorded in treatment $T_{9}$ followed by $\mathrm{T}_{10}$ (2.08) and $\mathrm{T}_{8}$ (1.87) at 60 DAFS. The lowest (0.97) was observed in $\mathrm{T}_{12}$ (control) treated plant. Significantly the highest (13.17\%) fruit retention per plant was observed in $\mathrm{T}_{8}$ treated plant followed by $\mathrm{T}_{9}$ (12.83\%) and $\mathrm{T}_{10}(12.83 \%)$ and the lowest (8\%) was found in $\mathrm{T}_{12}$ (control) treated plant at $60 \mathrm{DAFS}$ (Table 1). There is no available report on the contribution of NPK + Zinc sulphate + Gypsum + CD in the reduction of anthracnose of mango. However, the present results were similar to that of Symal and Mishra (1989) who observed that combination of NPK gave the highest (4.4) fruit retention per inflorescence. There was significant difference in the total number of fruits per plant due to different treatments (Table 1). The highest (56.67) number of fruits per plant was found in $T_{9}$ treated plant followed by $T_{8}$ (45.50), $T_{10}$ (38.50) and $T_{1}$ (34.50) and the lowest (19.67) number was recorded from $T_{12}$ (control) treated plant. Total number of fruits per plant was higher in $T_{9}$ (NPK + Zinc sulphate + Gypsum $+C D$ ) than control. This result was due to plants attained higher fruit retention and less fruits infection in this treatment, which led to higher yield per plant. Weight of individual fruit significantly differed among the different treatments. The highest $(203.50 \mathrm{~g})$ weight of individual fruit was observed in $\mathrm{T}_{12}$ (control) plant and the lowest $(185 \mathrm{~g})$ in $T_{9}$ treated plant. Treatment $T_{9}$ gave the highest $(7.76 \mathrm{~kg})$ fresh fruit yield 
per plant followed by $T_{8}(6.08 \mathrm{~kg}), \mathrm{T}_{10}(4.98 \mathrm{~kg})$ and $\mathrm{T}_{1}(4.29 \mathrm{~kg})$. The lowest $(2.42 \mathrm{~kg})$ yield per plant was obtained from $T_{12}$ treated plant. The highest $\left(12.41 \mathrm{t} / \mathrm{ha}\right.$ ) yield was obtained from treatment $T_{9}$ followed by $T_{8}(9.72 \mathrm{t} / \mathrm{ha}), \mathrm{T}_{10}(7.96 \mathrm{t} / \mathrm{ha})$ and $\mathrm{T}_{1}(6.86 \mathrm{t} / \mathrm{ha})$ and the lowest $(3.88 \mathrm{t} / \mathrm{ha})$ was obtained from $\mathrm{T}_{12}$ treated plant. Healthy fruits yield per plant and per hectare were found the highest in $T_{9}$ treatment (NPK + Zinc sulphate + Gypsum + CD) than control, because this treatment $\left(T_{9}\right)$ produced the highest number of healthy fruits per plant, which carried to the highest yield per hectare. This result was close to agreement with Singh et al. (1990). They reported that the combined doses of organic and inorganic form of nitrogen and urea along with FYM mixture gave very low disease and the highest yield of mango.

The combined effect of year and fertilizer was found significant in respect of fruit set per inflorescence (Table 2). It was observed that $2^{\text {nd }}$ year $\times T_{9}$ produced the highest (17.80) fruit set per inflorescence while $1^{\text {st }}$ year $x$ control control $\left(T_{12}\right)$ gave the lowest $(12.13)$ in this regard. Significant combined effect was observed in terms of fruit retention per inflorescence and per plant at different days after fruit set (DAFS) due to different year and fertilizers. The highest (2.40) number of fruit retention was recorded from $2^{\text {nd }}$ year $\times T_{9}$ at 60 DAFS and the lowest $(0.93)$ was observed in $1^{\text {st }}$ year $\times \mathrm{T}_{12}$ (control) plant at same DAFS. The highest $(14.33 \%)$ fruit retention per plant was observed in $2^{\text {nd }}$ year $x T_{9}$ treated plant followed by $1^{\text {st }}$ year $\times T_{8}(13.33 \%)$ and the lowest $(7.67 \%)$ was found in $1^{\text {st }}$ year $\times T_{12}$ (control) treatment at same DAFS. The highest (73.00) number of fruits per plant was found in $2^{\text {nd }}$ year $\times T_{9}$ treated plant followed by $2^{\text {nd }}$ year $\times T_{8}(66.00), 2^{\text {nd }}$ year $\times T_{1}$ (49.00) and $2^{\text {nd }}$ year $\times T_{2}(48.00)$ and the lowest (19.00) number was recorded from $T_{12}$ (control) in $1^{\text {st }}$ year. Significantly the highest $(207 \mathrm{~g})$ weight of individual fruit was observed in $1^{\text {st }}$ year $\times \mathrm{T}_{12}$ (control) plant and the lowest $(177 \mathrm{~g})$ was observed from $2^{\text {nd }}$ year $\times T_{9}$ treatment $($ Table 2$)$. In $2^{\text {nd }}$ year $x T_{9}$ gave the highest $(9.53 \mathrm{~kg})$ fresh fruit yield per plant followed by $2^{\text {nd }}$ year $\times T_{8}(8.80 \mathrm{~kg}), 1^{\text {st }}$ year $\times T_{9}(6.00 \mathrm{~kg}), 2^{\text {nd }}$ year $\times \mathrm{T}_{1}(5.72 \mathrm{Kg})$ and 2 nd year $\times \mathrm{T}_{2}(5.50 \mathrm{~kg})$ and the lowest $(1.58 \mathrm{~kg})$ yield per plant was obtained from $1^{\text {st }}$ year $x T_{12}$ (control) treatment. The highest $(15.22 \mathrm{t} / \mathrm{ha}$ ) yield was obtained from treatment $2^{\text {nd }}$ year $x T_{9}$ followed by $2^{\text {nd }}$ year $x T_{8}(14.08 \mathrm{t} / \mathrm{ha}), 2^{\text {nd }}$ year $\times T_{1}(9.15$ $\mathrm{t} / \mathrm{ha})$ and $2^{\text {nd }}$ year $\times \mathrm{T}_{2}(8.80 \mathrm{t} / \mathrm{ha})$ and the lowest $(2.95 \mathrm{t} / \mathrm{ha})$ was found in $1^{\text {st }}$ year $\times \mathrm{T}_{12}$ treated plant (Fig. 1). The highest healthy fruits yield per plant and per hectare was recorded from $2^{\text {nd }}$ year with $T_{9}$. In $2^{\text {nd }}$ year with $T_{9}$ resulted better performance in respect of yield and yield component. The possible result of higher yield in these treatments was due to the fact that plants of these treatments had more number of fruits per plant than control. In $2^{\text {nd }}$ year the highest (3.33) BCR was obtained from treatment $T_{9}$ and the lowest (1.95) BCR was obtained from $T_{2}$ treated plant (Table 2).

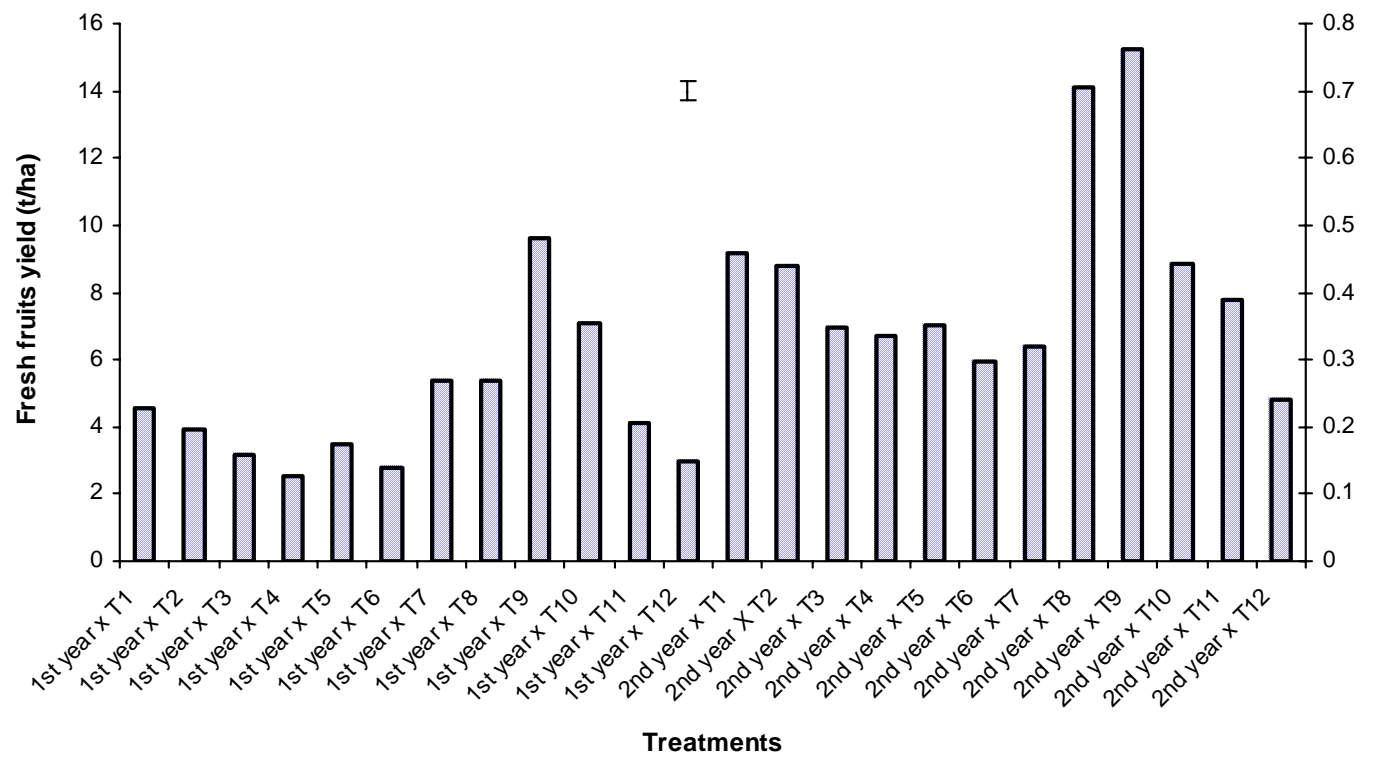

Fig. 1. Combined effect of year and fertilizers on fresh fruits yield of mango cv. Amrapali. Vertical bar represent LSD at 5\% levelof significance. 
Table 2. Combined effect of year and fertilizers on fruit set, fruit retention and yield of mango cv Amrapali

\begin{tabular}{|c|c|c|c|c|c|c|c|c|c|c|c|}
\hline \multirow[t]{2}{*}{ Treatments } & \multirow[t]{2}{*}{ FS/I } & \multicolumn{3}{|c|}{$\begin{array}{c}\text { Fruit } \\
\text { retention/inflorescence } \\
\text { at different DAFS }\end{array}$} & \multicolumn{3}{|c|}{$\begin{array}{c}\text { Fruit } \\
\text { retention/plant (\%) } \\
\text { at different DAFS }\end{array}$} & \multirow[t]{2}{*}{$\begin{array}{l}\text { TNFI } \\
\text { plant }\end{array}$} & \multirow[t]{2}{*}{$\begin{array}{l}\text { Individual } \\
\text { fruits wt. } \\
\text { (g) }\end{array}$} & \multirow{2}{*}{$\begin{array}{l}\text { HF } \\
\text { yield } / \\
\text { plant } \\
\text { (kg) }\end{array}$} & \multirow[t]{2}{*}{ BCR } \\
\hline & & 20 & 40 & 60 & 20 & 40 & 60 & & & & \\
\hline 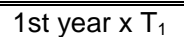 & 13.33 & 5.47 & 2.00 & \begin{tabular}{c|}
1.27 \\
\end{tabular} & 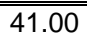 & 15.00 & 10.00 & 20.00 & 203 & 2.86 & 1.45 \\
\hline 1st year $\times T_{2}$ & 15.33 & 5.67 & 2.47 & 1.33 & 37.33 & 16.33 & 9.00 & 17.00 & 195 & 2.11 & 0.76 \\
\hline 1 st year $\times \mathrm{T}_{3}$ & 14.27 & 6.13 & 1.40 & 1.13 & 45.67 & 10.67 & 8.67 & 14.00 & 194 & 1.99 & 1.40 \\
\hline 1st year $\times \mathrm{T}_{4}$ & 12.20 & 5.80 & 1.73 & 1.00 & 47.33 & 14.33 & 8.33 & 11.67 & 200 & 1.58 & 1.03 \\
\hline 1 st year $\times T_{5}$ & 14.53 & 5.67 & 2.40 & 1.47 & 39.67 & 16.33 & 10.33 & 15.00 & & 2.17 & 1.42 \\
\hline 1st year $\times \mathrm{T}_{6}$ & 11.13 & 5.47 & 1.80 & 1.20 & 49.00 & 16.00 & 11.00 & 12.00 & 194 & 1.75 & 1.32 \\
\hline $1^{\text {st }}$ year $\times T_{7}$ & 16.13 & 6.33 & 2.53 & 1.40 & 40.00 & 15.67 & 9.33 & 24.00 & 198 & 3.37 & 2.50 \\
\hline 1 st year $\times T_{8}$ & 13.80 & 6.80 & 2.53 & 1.73 & 51.00 & 20.00 & 13.33 & 25.00 & 200 & 3.35 & 0.99 \\
\hline 1 st year $\times T_{9}$ & 17.40 & 8.40 & 3.67 & 2.20 & 48.00 & 21.00 & 12.67 & 40.33 & 193 & 6.00 & 2.81 \\
\hline 1st year $\times \mathrm{T}_{10}$ & 14.87 & 6.93 & 2.73 & 1.87 & 47.67 & 18.36 & 12.58 & 31.00 & 20 & 4.41 & 2.46 \\
\hline 1 st y & 12.53 & 5.27 & 1.73 & 1.40 & 42.00 & 13.81 & 11.17 & 19.00 & 203 & 2.57 & 1.47 \\
\hline 1 st ye & 12.13 & 5.27 & 1.53 & 0.93 & 43.33 & 13.00 & 7.67 & 13.33 & 207 & 1.84 & 1.46 \\
\hline $2^{\text {nd }} y$ & 14.20 & 5.20 & 2.20 & 1.80 & 36.67 & 16.00 & 12.67 & 49.00 & 182 & 5.72 & 2.80 \\
\hline $2^{\text {nd }}$ year $\times T_{2}$ & 15.60 & 6.20 & 2.80 & $\begin{array}{l}1.00 \\
1.60\end{array}$ & 41.00 & 18.33 & 10.67 & 48.00 & 182 & 5.50 & 1.95 \\
\hline $2^{\text {nd }}$ year $x T_{3}$ & 15.80 & 6.60 & 2.60 & 1.40 & 42.33 & 17.00 & 9.00 & 41.00 & & 4.35 & 2.93 \\
\hline $2^{\text {nd }}$ year $\times T_{4}$ & 14.60 & 6.60 & 2.20 & 1.20 & 45.33 & 15.33 & 8.33 & 36.00 & 192 & 4.20 & 2.60 \\
\hline $2^{\text {nd }}$ year $\times T_{5}$ & 16.20 & 6.50 & 2.80 & 1.80 & 40.33 & 18.00 & 11.00 & 41.00 & 189 & 4.37 & 2.73 \\
\hline $2^{\text {nd }}$ year $\times T_{6}$ & 13.60 & 5.80 & 2.40 & 1.40 & 42.67 & 17.00 & 10.67 & 34.00 & 192 & 3.70 & 2.60 \\
\hline $2^{\text {nd }}$ year $\times T_{7}$ & 12.80 & 4.80 & 2.00 & $\begin{array}{l}1.40 \\
1.60\end{array}$ & 38.67 & 16.00 & 12.67 & 35.00 & 192 & 4.10 & 2.50 \\
\hline $2^{\text {nd }}$ year $x T_{8}$ & 15.60 & 7.00 & 2.80 & 2.00 & 45.67 & 18.00 & 13.00 & 66.00 & 179 & 8.80 & 2.50 \\
\hline $2^{\text {nd }}$ year $\times T_{9}$ & 17.80 & 8.80 & 3.40 & 2.40 & 50.00 & 19.33 & 14.33 & 73.00 & 177 & 9.53 & 3.33 \\
\hline $2^{\text {nd }}$ year $\times T_{10}$ & 17.60 & 8.50 & 2.80 & 2.30 & 49.00 & 16.00 & 13.00 & 46.00 & 182 & 5.45 & 2.71 \\
\hline $2^{\text {nd }}$ year $\times T_{11}$ & 17.00 & 7.00 & 2.60 & 2.00 & 41.67 & 15.67 & 12.00 & 43.00 & 187 & 4.86 & 2.66 \\
\hline $2^{\text {nd }}$ year $x T_{12}$ & 11.80 & 4.40 & 1.60 & 1.00 & 37.67 & 13.67 & 8.33 & 26.00 & 200 & 3.00 & 2.37 \\
\hline LSD 5\% & 1.78 & 1.47 & 0.47 & 0.27 & 3.55 & 2.03 & 1.31 & 1.54 & 10.93 & 0.62 & - \\
\hline $1 \%$ & 2.95 & 1.96 & 0.63 & 0.36 & 4.74 & 2.71 & 1.75 & 2.06 & 14.60 & 0.82 & - \\
\hline $\begin{array}{c}\text { Level of } \\
\text { Significance }\end{array}$ & ** & ** & ** & ** & ** & ** & ** & ** & ** & ** & - \\
\hline
\end{tabular}

$\mathrm{FS} / \mathrm{I}=$ Fruit set/Inflorescence at the initial stage

DAFS = Days after fruit set

TNF $=$ Total number of fruits

$\mathrm{HF}=$ Healthy fruit

DF = Diseased fruit

** $=$ Significant at $1 \%$ level

Spacing $=2.5 \mathrm{~m} \times 2.5 \mathrm{~m}$

$\mathrm{BCR}=$ Gross return $/$ Total cost of production

Note $=$ Price of mango was considered to be TK $20 / \mathrm{kg}$

$\mathrm{T}_{1}=$ Cowdung $(\mathrm{CD})$

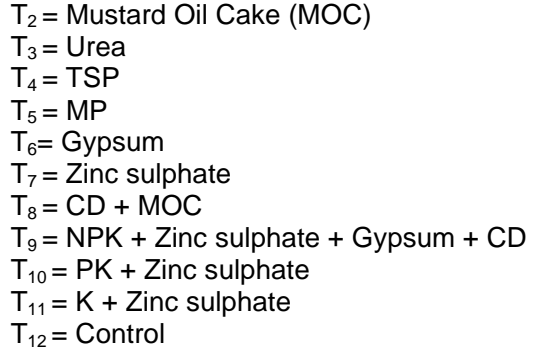

\section{Disease incidence}

After harvest 10 fruits of each treatments were randomly selected for observing the disease incidence and severity. There was highly significant variation was observed in respect of disease incidence and severity (Table 3$)$. It was found that the highest $(49.45 \%)$ incidence was found in $1^{\text {st }}$ year and the lowest $(41.50 \%)$ in $2^{\text {nd }}$ year at 10 days after harvest. Insignificant effect on fruit area diseased at different DAH as influenced by different year (Table 3 ).

The highest (64\%) incidence was found in $\mathrm{T}_{12}$ (control) and the lowest $(23.33 \%)$ from $\mathrm{T}_{9}$ treated fruits followed by $\mathrm{T}_{10}(30 \%) \mathrm{T}_{8}(30 \%)$ and $\mathrm{T}_{5}(35 \%)$ at 10 days after harvest (Table 3 ). Significantly the maximum (3.67\%) fruit area diseased was found in $T_{12}$ and minimum (0.50) fruit area diseased was observed in $T_{9}$ treated fruits followed by $T_{5}(0.84 \%), T_{10}(1.00 \%)$ and $T_{2}$ $(1.17 \%)$. This result was found due to the application of mixed fertilizers, which resulted the lowest 
fruit infection. Therefore, disease incidence and severity was less in $T_{9}$ treatment than control. The present results were similar to Rahman and Hossain (1988). They reported that application of NPK reduced the disease severity of mango. Hossain et al. (1996) also reported the same in this regard. He stated that mixed application of manures and fertilizers resulted the lowest fruit infection. He also stated that potassium increased the diseased resistance against the pathogen.

Table 3. Effect of manures and fertilizers on disease incidence and severity of anthracnose disease onmango cv Amrapali

\begin{tabular}{|c|c|c|c|c|c|c|}
\hline \multirow{2}{*}{ Treatments } & \multicolumn{3}{|c|}{ Incidence (\%) at DAH } & \multicolumn{3}{|c|}{ Severityl FAD (\%) at DAH } \\
\hline & 6 & 8 & 10 & 6 & 8 & 10 \\
\hline Ist year & 28.89 & 37.22 & 49.45 & 0.75 & 1.06 & 1.75 \\
\hline 2nd year & 24.17 & 31.92 & 41.50 & 0.72 & 0.97 & 1.53 \\
\hline LSD $5 \%$ & 1.72 & 11.64 & 2.76 & 0.32 & 0.29 & 0.37 \\
\hline $1 \%$ & 2.85 & 19.30 & 4.58 & 0.52 & 0.48 & 0.62 \\
\hline Level of significance & 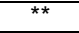 & NS & $\star \star$ & NS & NS & NS \\
\hline $\mathrm{T}_{1}$ & 26.67 & 36.67 & 48.39 & 0.67 & 1.17 & 1.50 \\
\hline $\mathrm{T}_{2}$ & 26.67 & 33.34 & 46.67 & 0.67 & 0.67 & 1.17 \\
\hline $\mathrm{T}_{3}$ & 36.67 & 48.33 & 58.34 & 1.33 & 1.33 & 2.17 \\
\hline $\mathrm{T}_{4}$ & 35.00 & 46.67 & 61.67 & 1.00 & 1.34 & 2.50 \\
\hline $\mathrm{T}_{5}$ & 18.34 & 25.00 & 35.00 & 0.33 & 0.50 & 0.84 \\
\hline $\mathrm{T}_{6}$ & 31.67 & 40.50 & 51.67 & 1.00 & 1.50 & 1.67 \\
\hline $\mathrm{T}_{7}$ & 36.67 & 44.34 & 58.33 & 1.00 & 1.34 & 2.17 \\
\hline $\mathrm{T}_{8}$ & 21.67 & 25.00 & 31.67 & 0.33 & 0.50 & 0.84 \\
\hline $\mathrm{T}_{9}$ & 11.67 & 16.67 & 23.33 & 0.165 & 0.33 & 0.50 \\
\hline $\mathrm{T}_{10}$ & 15.00 & 16.67 & 30.00 & 0.33 & 0.67 & 1.00 \\
\hline $\mathrm{T}_{11}$ & 18.34 & 30.00 & 36.67 & 0.50 & 1.00 & 1.67 \\
\hline $\mathrm{T}_{12}$ & 40.00 & 51.67 & 64.00 & 1.50 & 1.84 & 3.67 \\
\hline LSD 5\% & 3.79 & 5.79 & 5.02 & 0.22 & 0.19 & 0.43 \\
\hline $1 \%$ & 5.06 & 7.73 & 6.70 & 0.29 & 0.25 & 0.58 \\
\hline Level of significance & 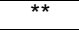 & ** & ** & ** & 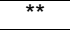 & 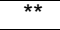 \\
\hline
\end{tabular}

The combined effect of disease incidence of anthracnose as influenced by different year and treatments is presented (Fig 2). The highest (66.67\%) incidence was found in $1^{\text {st }}$ year $\times \mathrm{T}_{12}$ (control) treated fruits and the lowest $(23.33 \%)$ in $2^{\text {nd }}$ year $\times T_{9}$ treated fruits at 10 days after harvest. The maximum (4\%) fruit area diseased was found in $1^{\text {st }}$ year $\times T_{12}$ (control) treated fruits and minimum (0.33) fruit area diseased was observed in $2^{\text {nd }}$ year $\times T_{9}$ followed by $1^{\text {st }}$ year $\times T_{9}(0.67 \%)$.

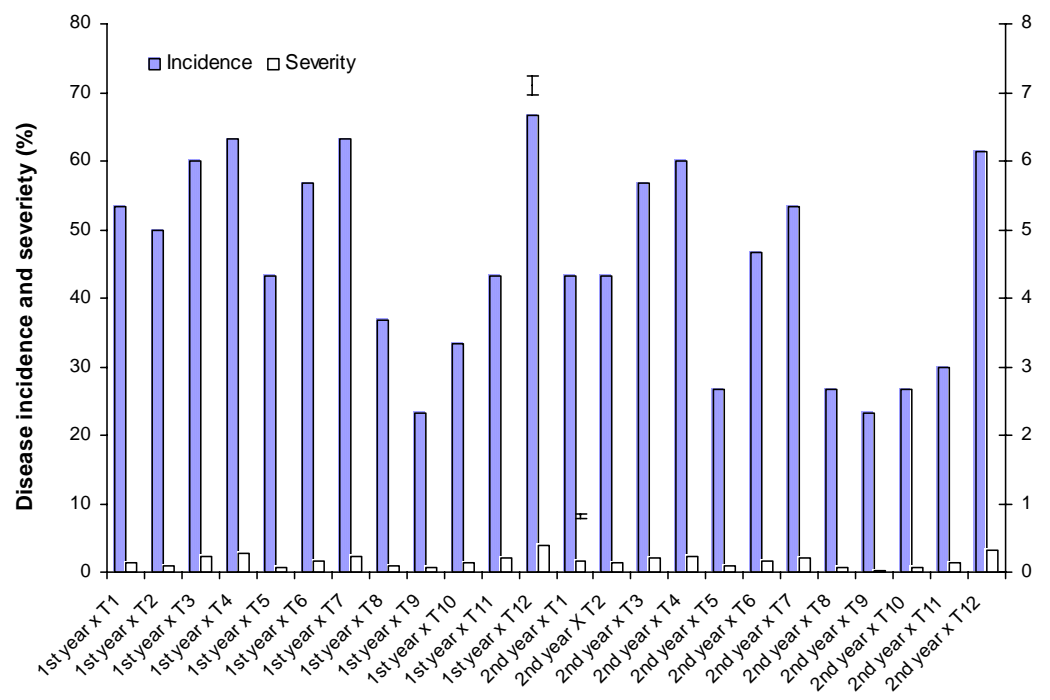

Treatments

Fig. 2. Combined effect of year and fertilizers on disease incidence and severiety of mango cv. Amrapali at 10 days after harvest. Vertical bars represent LSD at $5 \%$ level of significance. 


\section{Fruit quality}

Different years showed significant effect on number of healthy and diseased fruits per inflorescence and per plant (Table 4). 1st year gave the lowest number and percentage of healthy (1.22 and 85.63 respectively) fruits per inflorescence and per plant and the highest (1.46 85.41 respectively) was found in $2^{\text {nd }}$ year (Table 4$)$. The highest number and percentage of diseased fruits $(0.25$ and 14.59 respectively) per inflorescence and per plant was found from $2^{\text {nd }}$ year and the lowest $(0.19$ and 14.37 respectively) was obtained from $1^{\text {st }}$ year. Significantly the highest (38.75) number of healthy fruits was found from $2^{\text {nd }}$ year and the lowest (17.42) was obtained from $1^{\text {st }}$ year (Table 4). Insignificant effect was observed on percentage of healthy fruits per plant due to different years. In respect of year, 1st year gave the lowest (2.78) number of diseased fruits per plant and the highest (6.08) was found in $2^{\text {nd }}$ year (Table 2). Insignificant effect was observed on percentage of diseased fruits per plant and total soluble solids due to different years.

Table 4. Effect of manures and fertilizers on fruit quality of mango cv Amrapali

\begin{tabular}{|c|c|c|c|c|c|c|c|c|c|}
\hline \multirow{2}{*}{ Treatments } & \multirow{2}{*}{$\begin{array}{c}\text { No. of } \\
\text { healthy } \\
\text { fruits/Inf. } \\
\text { at } 60 \\
\text { DAFS }\end{array}$} & \multirow{2}{*}{$\begin{array}{c}\text { No. of } \\
\text { healthy } \\
\text { fruits/plant } \\
\text { (\%) at } 60 \\
\text { DAFS }\end{array}$} & \multirow{2}{*}{$\begin{array}{l}\text { No. of } \\
\text { diseased } \\
\text { fruits/Inf. } \\
\text { at } 60 \\
\text { DAFS }\end{array}$} & \multirow{2}{*}{$\begin{array}{c}\text { No. of } \\
\text { diseased } \\
\text { fruits/plant } \\
\text { (\%) at } 60 \\
\text { DAFS }\end{array}$} & \multicolumn{2}{|c|}{ TNHF/plant } & \multicolumn{2}{|c|}{ TNDF/plant } & \multirow{2}{*}{ TSS } \\
\hline & & & & & No. & $\%$ & No. & $\%$ & \\
\hline $1^{\text {st }}$ year & 1.22 & 85.63 & 0.19 & 14.37 & 17.42 & 86.39 & 2.78 & 13.56 & 24.67 \\
\hline $2^{\text {nd }}$ year & 1.46 & 85.41 & 0.25 & 14.59 & 38.75 & 86.63 & 6.08 & 14.04 & 23.65 \\
\hline LSD $5 \%$ & 0.18 & 2.14 & 0.04 & 1.17 & 3.09 & 3.47 & 1.64 & 2.52 & 3.24 \\
\hline $1 \%$ & 0.30 & 3.55 & 0.07 & 1.94 & 5.12 & 5.75 & 2.73 & 4.19 & 5.37 \\
\hline Level of Significance & * & NS & * & NS & ** & NS & ** & NS & NS \\
\hline $\mathrm{T}_{1}$ & 1.32 & 85.70 & 0.22 & 14.31 & 29.67 & 86.36 & 4.83 & 13.65 & 24.50 \\
\hline $\mathrm{T}_{2}$ & 1.25 & 85.41 & 0.22 & 14.58 & 27.67 & 86.67 & 4.83 & 13.34 & 24.50 \\
\hline $\mathrm{T}_{3}$ & 1.07 & 84.63 & 0.20 & 15.38 & 23.50 & 85.85 & 4.00 & 14.15 & 22.50 \\
\hline $\mathrm{T}_{4}$ & 0.94 & 85.00 & 0.17 & 15.00 & 20.50 & 86.06 & 3.33 & 13.61 & 24.00 \\
\hline $\mathrm{T}_{5}$ & 1.41 & 86.26 & 0.23 & 13.75 & 24.50 & 87.40 & 3.50 & 12.60 & 24.75 \\
\hline $\mathrm{T}_{6}$ & 1.09 & 85.00 & 0.20 & 15.00 & 19.67 & 85.98 & 3.33 & 14.02 & 24.50 \\
\hline $\mathrm{T}_{7}$ & 1.29 & 85.67 & 0.22 & 14.34 & 25.17 & 85.52 & 4.33 & 14.48 & 24.50 \\
\hline $\mathrm{T}_{8}$ & 1.61 & 86.39 & 0.26 & 13.61 & 40.17 & 87.36 & 5.33 & 12.64 & 24.50 \\
\hline $\mathrm{T}_{9}$ & 2.04 & 87.62 & 0.29 & 12.39 & 50.67 & 89.69 & 6.00 & 10.31 & 26.67 \\
\hline $\mathrm{T}_{10}$ & 1.81 & 86.53 & 0.28 & 13.47 & 33.00 & 85.48 & 5.50 & 14.52 & 23.50 \\
\hline $\mathrm{T}_{11}$ & 1.44 & 84.65 & 0.26 & 15.36 & 26.50 & 85.53 & 4.50 & 14.48 & 23.50 \\
\hline $\mathrm{T}_{12}$ & 0.81 & 83.40 & 0.16 & 16.60 & 16.00 & 86.22 & 3.67 & 17.78 & 22.50 \\
\hline LSD $5 \%$ & 0.08 & 1.76 & 0.01 & 0.88 & 1.50 & 2.27 & 0.69 & 1.27 & 1.54 \\
\hline $1 \%$ & 0.11 & 2.35 & 0.02 & 1.17 & 2.00 & 3.04 & 0.92 & 1.70 & 2.90 \\
\hline Level of Significance & ** & $\star \star$ & $\star \star$ & ** & ** & ** & ** & ** & ** \\
\hline
\end{tabular}

DAP = Days after harvest

Inf. = Inflorescence

DAFS $=$ Days after fruit set

TNHF $=$ Total number of healthy fruits

TNDF $=$ Total number of diseased fruits

TSS $=$ Total soluble solids

** $=$ Significant at $1 \%$ level

* = Significant at $5 \%$ level

NS $=$ Not significant

$\mathrm{T}_{1}=$ Cowdung (CD)

$\mathrm{T}_{2}=$ Mustard Oil Cake (MOC)
$\mathrm{T}_{3}=$ Urea

$\mathrm{T}_{4}=\mathrm{TSP}$

$\mathrm{T}_{5}=\mathrm{MP}$

$\mathrm{T}_{6}=$ Gypsum

$\mathrm{T}_{7}=$ Zinc sulphate

$\mathrm{T}_{8}=\mathrm{CD}+\mathrm{MOC}$

$\mathrm{T}_{9}=\mathrm{NPK}+$ Zinc sulphate + Gypsum $+\mathrm{CD}$

$\mathrm{T}_{10}=\mathrm{PK}+$ Zinc sulphate

$\mathrm{T}_{11}=\mathrm{K}+$ Zinc sulphate

$\mathrm{T}_{12}=$ Control 
Different fertilizers showed significant difference on number of healthy and diseased fruits per inflorescence and per plant. The highest number and percentage of healthy fruits (2.04 and $87.62 \%$ respectively) per inflorescence and per plant was recorded from $\mathrm{T}_{9}$ treated plant and the lowest $\left(0.81\right.$ and $83.40 \%$ respectively) was found in $\mathrm{T}_{12}$ (control) treatment at 60 DAFS. The highest number and percentage of diseased fruits $(0.29$ and 12.39\%) per inflorescence and per plant was observed in $T_{9}$ treated plant and the lowest ( 0.16 and $16.60 \%$ respectively) from $\mathrm{T}_{4}$ treated plant at 60 DAFS. There was significant difference in the total number of fruits per plant due to different treatments (Table 4). Among the treatments, $T_{9}$ gave the highest number of healthy fruits (50.67) and the lowest (16 and ) was obtained from $\mathrm{T}_{12}$ treated plant. Percentage of healthy fruits per plant was significantly influenced by different treatments. Significantly the highest percentage (89.69) of healthy fruits per plant was recorded from $\mathrm{T}_{9}$ treated plant followed by treatments $T_{5}(87.40 \%)$ and $T_{8}(87.36 \%)$ and the lowest $(85.48 \%)$ was recorded from $\mathrm{T}_{10}$ (control) treated plant (Table 4). Among the different treatments, treatment $\mathrm{T}_{4}$ gave the lowest (3.33) number of diseased fruits per plant and the highest (7.76) was found in $\mathrm{T}_{9}$ treated plant. Percentage of diseased fruits per plant varied significantly due to different fertilizers. The highest percentage (17.78) of diseased fruits per plant was found in $\mathrm{T}_{12}$ (control) treated plant and the lowest $(10.31 \%)$ from $\mathrm{T}_{9}$ treated plant followed by $\mathrm{T}_{5}$ (12.60\%), $\mathrm{T}_{8}(12.64 \%)$ and $\mathrm{T}_{2}(13.34 \%)$. This result might be due to $\mathrm{T}_{9}$ treatment that reduced the fruit infection. Therefore, the number and percentage of healthy fruits were higher and percentage of diseased fruits was less. This result was close to the findings of Avilan (1972) who reported that application of NPK increased the fruit yield. There was significant difference in total soluble solids due to different fertilizers (Table 4). The highest (26.67) soluble solid was obtained form treatment $T_{9}$ followed by $T_{5}(24.75)$ and $\mathrm{T}_{8}(24.50)$ ) and the lowest (22.50) was recorded from $\mathrm{T}_{12}$ (control) treated plant.

Number of healthy fruits per inflorescence and per plant was found significant due to different year and fertilizers (Table 5). The highest (2.10) number of healthy fruits per inflorescence was recorded from $2^{\text {nd }}$ year $\times T_{9}$ treated plant and the lowest $(0.77)$ was found in $1^{\text {st }}$ year $\times \mathrm{T}_{12}$ (control) treated plant at 60 DAFS. At 60 DAFS $1^{\text {st }}$ year $\times T_{9}$ gave the highest percentage $(87.73 \%)$ of healthy fruits per plant followed by $2^{\text {nd }}$ year $x T_{9}$ $(87.50 \%)$ and $2^{\text {nd }}$ year $\times T_{10}(86.96 \%)$ the lowest $(82.80 \%)$ was obtained from $1^{\text {st }}$ year $x$ $\mathrm{T}_{12}$ treated plant. The highest $(0.30)$ number of diseased fruits per inflorescence was observed in $2^{\text {nd }}$ year $\times T_{9}$ and the lowest (0.15) was recorded from 1 st year $\times T_{4}$ treated plant at 60 DAFS. The highest percentage (17.20\%) number of diseased fruits per plant was recorded from $1^{\text {st }}$ year $\times \mathrm{T}_{12}$ (control) treated plant and the lowest $(12.27 \%)$ from $1^{\text {st }}$ year $\times T_{9}$ treated plant at 60 DAFS. At harvest it was found that the different year and fertilizers had significant influence on total number of healthy fruits per plant (Table 5). Among the treatments, in $2^{\text {nd }}$ year $x T_{9}$ gave the highest $(65.00)$ number of healthy fruits followed by $2^{\text {nd }}$ year $\times T_{8}(59.00), 2^{\text {nd }}$ year $\times T_{1}(42.00)$ and $2^{\text {nd }}$ year $\times T_{10}(40.00)$ and the lowest (11.00) was found in $1^{\text {st }}$ year $\times T_{12}$ (control). The highest percentage (90.33) of healthy fruits per plant was recorded from $1^{\text {st }}$ year $\times T_{9}$ treated plant and the lowest $(80.77 \%)$ was recorded from $2^{\text {nd }}$ year $\times \mathrm{T}_{12}$ (control) treated plant. Among the different year and treatments, $1^{\text {st }}$ year $\times T_{2}$ gave the lowest (1.67) number of diseased fruits per plant and the highest (8.00) number of disease fruits per plant was found in $2^{\text {nd }}$ year $\times T_{9}$ treated plant. The highest percentage (19.23) of diseased fruits per plant was found in $2^{\text {nd }}$ year $\times T_{12}$ (control) treated plant and the lowest $(9.67 \%)$ from $1^{\text {st }}$ year $\times T_{9}$ treated plant. The highest $(27.00)$ soluble solid was obtained form $1^{\text {st }}$ year $\times T_{9}$ followed by $2^{\text {nd }}$ year $x T_{9}(26.33)$ and the lowest (22.00) from $2^{\text {nd }}$ year $x T_{12}$ (control). 
Table 5. Combined effect of year and fertilizers on fruit quality of mango

\begin{tabular}{|c|c|c|c|c|c|c|c|c|c|}
\hline \multirow[t]{2}{*}{ Treatments } & \multicolumn{2}{|c|}{$\begin{array}{c}\text { Healthy } \\
\text { fruits/Inflorescence } \\
\text { at } 60 \text { DAFS }\end{array}$} & \multicolumn{2}{|c|}{$\begin{array}{c}\text { Diseased } \\
\text { fruits/Inflorescence } \\
\text { at } 60 \text { different DAFS }\end{array}$} & \multicolumn{2}{|c|}{$\begin{array}{l}\text { TNHFIPlant } \\
\text { (at harvest) }\end{array}$} & \multicolumn{2}{|c|}{$\begin{array}{l}\text { TNDF/Plant } \\
\text { (at harvest) }\end{array}$} & \multirow[t]{2}{*}{ TSS } \\
\hline & No & $\%$ & No & $\%$ & No. & $\%$ & No. & $\%$ & \\
\hline 1st year $\times \mathrm{T}_{1}$ & 1.09 & 85.83 & 0.18 & 14.17 & 17.33 & 87.00 & 2.67 & 13.00 & 25.00 \\
\hline 1st year $x \mathrm{~T}_{2}$ & 1.15 & 86.47 & 0.18 & 13.53 & 15.33 & 90.00 & 1.67 & 10.00 & 25.00 \\
\hline 1st year $\times \mathrm{T}_{3}$ & 0.95 & 84.96 & 0.17 & 15.05 & 12.00 & 86.33 & 2.00 & 13.67 & 23.00 \\
\hline 1st year $\times \mathrm{T}_{4}$ & 0.85 & 85.00 & 0.15 & 15.00 & 10.00 & 86.67 & 1.67 & 13.33 & 24.00 \\
\hline 1st year $x \mathrm{~T}_{5}$ & 1.27 & 86.39 & 0.20 & 13.61 & 13.00 & 87.00 & 2.00 & 13.00 & 25.00 \\
\hline 1st year $\times \mathrm{T}_{6}$ & 1.02 & 85.00 & 0.18 & 15.00 & 10.33 & 86.67 & 1.67 & 13.33 & 25.00 \\
\hline 1st year $\times T_{7}$ & 1.20 & 85.71 & 0.20 & 14.29 & 20.33 & 85.33 & 3.67 & 14.67 & 25.33 \\
\hline 1st year $\times \mathrm{T}_{8}$ & 1.51 & 87.28 & 0.22 & 12.72 & 21.33 & 85.33 & 3.67 & 14.67 & 25.00 \\
\hline 1st year $\times \mathrm{T}_{9}$ & 1.98 & 87.73 & 0.27 & 12.27 & 36.33 & 90.33 & 4.00 & 9.67 & 27.00 \\
\hline 1st year $\times \mathrm{T}_{10}$ & 1.61 & 86.10 & 0.26 & 13.90 & 26.00 & 84.00 & 5.00 & 16.00 & 25.00 \\
\hline 1st year $\times \mathrm{T}_{11}$ & 1.18 & 84.29 & 0.22 & 15.71 & 16.00 & 85.00 & 3.00 & 15.00 & 24.00 \\
\hline 1st year $\times \mathrm{T}_{12}$ & 0.77 & 82.80 & 0.16 & 17.20 & 11.00 & 83.67 & 2.33 & 16.33 & 23.00 \\
\hline $2^{\text {nd }}$ year $\times T_{1}$ & 1.54 & 85.56 & 0.26 & 14.44 & 42.00 & 85.71 & 7.00 & 14.29 & 24.00 \\
\hline $2^{\text {nd }}$ year $\times T_{2}$ & 1.35 & 84.37 & 0.25 & 15.63 & 40.00 & 83.33 & 8.00 & 16.67 & 24.00 \\
\hline $2^{\text {nd }}$ year $\times T_{3}$ & 1.18 & 84.29 & 0.22 & 15.71 & 35.00 & 85.37 & 6.00 & 14.63 & 22.00 \\
\hline $2^{\text {nd }}$ year $\times \mathrm{T}_{4}$ & 1.02 & 85.00 & 0.18 & 15.00 & 31.00 & 86.11 & 5.00 & 13.89 & 24.00 \\
\hline $2^{\text {nd }}$ year $\times T_{5}$ & 1.55 & 86.12 & 0.25 & 13.88 & 36.00 & 87.80 & 5.00 & 12.20 & 24.50 \\
\hline $2^{\text {nd }}$ year $\times T_{6}$ & 1.15 & 85.00 & 0.21 & 15.00 & 29.00 & 85.29 & 5.00 & 14.71 & 24.00 \\
\hline $2^{\text {nd }}$ year $x T_{7}$ & 1.37 & 85.62 & 0.23 & 14.38 & 30.00 & 87.71 & 5.00 & 14.29 & 24.00 \\
\hline $2^{\text {nd }}$ year $\times T_{8}$ & 1.71 & 85.50 & 0.29 & 14.50 & 59.00 & 89.39 & 7.00 & 10.61 & 24.00 \\
\hline $2^{\text {nd }}$ year $\times T_{9}$ & 2.10 & 87.50 & 0.30 & 12.50 & 65.00 & 89.04 & 8.00 & 10.96 & 26.33 \\
\hline $2^{\text {nd }}$ year $\times T_{10}$ & 2.00 & 86.96 & 0.29 & 13.04 & 40.00 & 86.96 & 6.00 & 13.04 & 22.00 \\
\hline $2^{\text {nd }}$ year $\times \mathrm{T}_{11}$ & 1.70 & 85.00 & 0.30 & 15.00 & 37.00 & 86.05 & 6.00 & 13.95 & 23.00 \\
\hline $2^{\text {nd }}$ year $\times T_{12}$ & 0.84 & 84.00 & 0.16 & 16.00 & 21.00 & 80.77 & 5.00 & 19.23 & 22.00 \\
\hline \multirow[t]{3}{*}{ LSD } & 0.12 & 2.48 & 0.05 & 1.24 & 2.12 & 3.21 & 0.97 & 1.80 & 2.17 \\
\hline & 0.16 & 3.32 & 0.07 & 1.66 & 2.83 & 4.29 & 1.30 & 2.40 & 2.90 \\
\hline & ** & $\star \star$ & $\star \star$ & ** & $\star \star$ & $\star \star$ & ** & ** & ** \\
\hline \multicolumn{3}{|c|}{$\begin{array}{l}\text { DAFS }=\text { Days after fruit set } \\
\text { TNHF = Total number of healthy fruits } \\
\text { TNDF = Total number of diseased fruits } \\
\text { TSS = Total Soluble Solids } \\
\star \star \\
\mathrm{T}_{1}=\text { Significant at } 1 \% \text { level } \\
\mathrm{T}_{1} \text { Cowdung (CD) } \\
\mathrm{T}_{2}=\text { Mustard Oil Cake (MOC) } \\
\mathrm{T}_{3}=\text { Urea }\end{array}$} & & $\begin{array}{l}T_{4}=T \\
T_{5}=1 \\
T_{6}=\mathrm{G} \\
T_{7}=Z \\
T_{8}=C \\
T_{9}=1 \\
T_{10}= \\
T_{11}= \\
T_{12}=\end{array}$ & $\begin{array}{l} \\
\text { sum } \\
+ \text { sulph } \\
+ \text { MOC } \\
+ \text { Zin } \\
+ \text { Zinc } \\
\text { Zinc } s \\
\text { ntrol }\end{array}$ & $\begin{array}{l}\text { ulphate } \\
\text { Iphate } \\
\text { hate }\end{array}$ & לypsur & $C D$ & \\
\hline
\end{tabular}

\section{LITERATURE CITED}

Avilan, R. L. 1972. Mango fertilization on soils of the Maracay Series. Agronomia Tropical, 22 : 535-539.

BBS. 2005. Monthly Statistical Bulletin, Bangladesh (July,2002). Bangladesh Bureau of Statistics, Statistics Division, Ministry of Planning. Gvernment of The Peoples' Republic of Bangladesh. pp. 390-393.

Hossain M. D., Meah M. B. and Kashem M. A. 1996. Biochemical changes of guava fruit due to infection of anthracnose as influenced by soil amendments. Bangladesh J. Plant Path., 12 (1-2), 33-36.

Hossain, A. K. M. A. and Ahmed A. 1994. A monograph on mango varieties in Bangladesh. HRC-BARI and FAO/UNDP Mango Improvement Project. p. 3.

Horsfall, J. G. and R. W. Barratt. 1945. An improved grading system for measuring plant diseases. Phytopath., $35: 655$.

Rahman, M. A. and Hossain, S.1988. Annual Report for 1987-88. Plant Pathology Division, BARI, Joydebpur, pp.64-67.

Singh, A., Bhowmik T. P., and Choudhury B. S. 1990. Effects of soil amendment with inorganic and organic sources of nitrogenous manures on the incidence of root rot and seed yield in sesamum. Indian Phytopath., 43(3), 442-443.

Symal, M. M. and. Mishra K. A. 1989. Effect of NPK on growth, flowering, fruiting and quality of mango. Acta Hort., 231(1), 276-281. 